\title{
Therapeutic Effects of Interleukin-4 Gene Transfer in Experimental Inflammatory Bowel Disease
}

\author{
Cory M. Hogaboam, ${ }^{*}$ Bruce A. Vallance, ${ }^{\star}$ Ashesh Kumar, ${ }^{\star}$ Christina L. Addison, ${ }^{\S}$ Frank L. Graham,,${ }^{\S}$ Jack Gauldie, ${ }^{\ddagger}$ \\ and Stephen M. Collins* \\ Intestinal Disease Research Programme, *Department of Medicine and Molecular Virology and Immunology, ${ }^{\ddagger}$ Department of Pathology \\ and ${ }^{\S}$ Department of Biology, McMaster University, Hamilton, Ontario, Canada
}

\begin{abstract}
Inflammatory bowel disease (IBD) is characterized by altered immunoregulation and augmented intestinal synthesis of nitric oxide. The purpose of this study was to determine the effects of exogenous IL-4, introduced by a recombinant human type 5 adenovirus (Ad5) vector, on the tissue injury associated with an experimental model of colonic immune activation and inflammation. Colitis was induced in rats by the intrarectal administration of trinitrobenzene sulfonic acid (TNB) dissolved in 50\% ethanol, and control rats received saline via the same route. $1 \mathrm{~h}$ later, all rats were randomized into two groups. The first group was injected intraperitoneally (ip) with $3.0 \times 10^{6}$ plaque forming units (PFUs) of Ad5 transfected with murine interleukin-4 (Ad5IL-4) and the second group was injected ip with the same amount of Ad5 expressing the Escherichia coli Lac Z gene (Ad5LacZ). One-half of the colitic and control rats were injected again with $3.0 \times 10^{6}$ PFUs of Ad5IL-4 or Ad5LacZ on day 3 of the 6-d study. When introduced once or twice via the peritoneal route into control rats, Ad5LacZ was localized to the serosal lining of the peritoneal cavity, the diaphragm and the liver on day 6 . One or two injections of Ad5IL-4 into rats also produced measurable levels of circulating IL-4. TNB-colitis in both Ad5LacZ-treated groups was associated with pronounced elevations in serum IFN- $\gamma$, and mucosal ulceration of the distal colon. Myeloperoxidase and inducible nitric oxide synthase II (NOS II) synthetic activity were also increased by 30 - and fivefold, respectively, above control levels in the distal colon. However, two injections of Ad5IL-4 into colitic rats caused the overexpression of IL-4, and significantly inhibited tissue damage, serum and colon IFN- $\gamma$ levels and myeloperoxidase activity in the distal colon. In addition, NOS II gene expression and NOS II nitric oxide synthesis was significantly inhibited. No therapeutic effect was observed in rats injected once with Ad5IL-4. Thus, IL-4, introduced by Ad5, is therapeutic during acute inflammation in
\end{abstract}

Address correspondence to Cory M. Hogaboam, Department of Pathology, University of Michigan Medical School, 1301 Catherine Road, Ann Arbor, MI 48109. Phone: 313-936-1020; FAX: 313-764-2397; E-mail: hogaboam@path.med.umich.edu

Received for publication 1 May 1997 and accepted in revised form 26 September 1997.

J. Clin. Invest.

(C) The American Society for Clinical Investigation, Inc. 0021-9738/97/12/2766/11 \$2.00

Volume 100, Number 11, December 1997, 2766-2776

http://www.jci.org the rat colon. The therapeutic effect of IL-4 was associated with an inhibition of inducible nitric oxide expression and a reduction in nitric oxide synthesis. (J. Clin. Invest. 1997. 100:2766-2776.) Key words: inflammatory bowel disease $\bullet$ interleukin-4 $\bullet$ nitric oxide $\bullet$ gene therapy • adenovirus

\section{Introduction}

The advent of technologies permitting the delivery of genomic material has allowed for the examination of the in vivo effects of increased cytokine synthesis on the development of and/or therapeutic resolution of disease. Many strategies for cytokine and other gene delivery exist, including injection of naked cDNA (1), cDNA inserted into lipid vehicles $(2,3)$ or cDNA incorporated into a virus (see reference 4 for review). Of the types of viral vectors (e.g., retrovirus, vaccinia, herpes virus, etc.) used for in vivo gene delivery, the replication-deficient recombinant human type 5 adenovirus $(\mathrm{Ad} 5)^{1}$ has gained the greatest prominence because Ad5 vectors can be grown in very high density and, unlike retrovirus, Ad5 can insert foreign genes into nondividing mammalian cells (5). Many investigators have shown that Ad5 vectors can successfully deliver mammalian cytokine genes to many different tissues and organs, including the gastrointestinal tract. For example, Braciak et al. (6) showed that Ad5 transfected with murine interleukin-6 cDNA induces elevated synthesis of this cytokine, particularly in the liver. We have also previously shown that Ad5 transfected with murine IL-4 cDNA (Ad5IL-4) can be delivered directly to the rodent intestine, resulting in measurable infection and pronounced changes in circulating IL-4 and intestinal function (7). Another advantage of this method of gene delivery is that Ad5 does not stably integrate into the genome of the host. Therefore, gene delivery through replication-deficient Ad5 provides an ideal method for studying the consequences of transitory increased synthesis of a single cytokine under in vivo conditions.

During what in vivo conditions would it be advantageous to augment levels of a particular cytokine through gene transfer? Using an Ad5-based gene delivery system, it has been possible to explore the transient role of various cytokines in pathological processes in the lung $(6,8)$ and the intestine $(7)$, and to test cytokine efficacy in the treatment of cancer $(9,10)$ and cardiovascular disease (11). In addition, the therapeutic implications of this approach are only now being realized in light of emerg-

1. Abbreviations used in this paper: Ad5IL-4, human ad5 adenovirus transfected with murine IL-4 cDNA; Ad5LacZ, human ad5 adenovirus transfected with $\beta$-galactosidase cDNA; IBD, inflammatory bowel disease; MPO, myeloperoxidase; NOS II, inducible nitric oxide synthase type II; PFU, plaque forming unit; TNB, trinitrobenzene sulphonic acid. 
ing evidence that systemic and, to a greater extent, mucosal $\mathrm{T}$ cell immunoregulation is maintained through the actions of antagonizing cytokines (12). Considerable interest in the role of cytokine balance in the gastrointestinal tract has surfaced because of the development of mice lacking important $\mathrm{T}$ cell immunoregulatory cytokines, and the characterization of cytokine profiles in inflammatory bowel disease (IBD). Specifically, it has been shown that disrupting the gene for IL-2 (13), IL-10 (14), or altering T cell regulation by MHC II or T cell receptor (15) gene disruption has significant negative consequences for the bowel and cytokine balance (16). Other studies have shown that the transfer of a certain population of purified $\mathrm{T}$ cells into immunocompromised mice predisposes them to colitis, and is associated with elevated secretion of IFN- $\gamma$ and TNF $\alpha(17,18)$. Consistent with these experimental findings, there is emerging clinical evidence that IBD is associated with altered mucosal immunoregulation, due in part to altered synthesis of cytokines by $\mathrm{T}$ and other immune cells and/ or impaired responses of these cells to immunoregulatory cytokines (19). For example, Kusugami et al. (12) showed that IBD is associated with the loss of IL- 2 secreting CD4 $4^{+} \mathrm{T}$ cells. Schreiber and colleagues have more recently shown that peripheral monocytes from IBD patients are partially resistant to the immunosuppressive effects of IL-4 (20) and that IL-10 synthesis is down-regulated in IBD (21). These findings have been impetus for further studies on the efficacy of cytokine antagonists or immunoregulatory cytokines themselves in the treatment of IBD. Accordingly, treatment of steroid refractory IBD patients with a monoclonal antibody directed against TNF $\alpha$ (22-24) or with recombinant human IL-10 (21) have both proven to be of therapeutic potential. Thus, restoring the cytokine imbalance by inhibiting the action of proinflammatory cytokines or by up-regulating the levels of immunomodulatory cytokines appear to be a promising new treatment for IBD (19).

Herein, we examined the therapeutic effects of increased synthesis of IL-4 after injection of Ad5IL-4 on the colonic inflammation associated with acute trinitrobenzene sulphonic acid (TNB)-colitis. This rat model was used because it has well-characterized histological similarities to IBD (25), and it responds favorably to many of the therapies used in the treatment of IBD (26). IL-4 was selected as a treatment modality in the present study due to its proven immunomodulatory, particularly in the balance of Th1 and Th2 cytokine generation in the gut (27), and its antiinflammatory effects (28). The findings of Gautam et al. (29) demonstrating that IL-4 had potent antiinflammatory actions in a murine model of contact sensitivity to trinitrochlorobenzene was one example that suggested to us that increased IL-4 synthesis in the TNB-model of colitis may lead to similar beneficial effects. Next, because it has been shown previously that IL-4 is a potent inhibitor of the inducible, calcium-independent isoform of nitric oxide synthase (NOS II) (see reference 30 for review) we also investigated the effects of increased synthesis of IL-4 on nitric oxide generation during TNB-colitis in rats. Many investigators have shown that clinical IBD is associated with increased mucosal production of nitric oxide and increased expression of NOS II (see reference 31 for overview). Using non-selective substrate inhibitors of NOS, we (32) and others (33-36) have shown that increased NOS II expression and activity in the large or small intestine after their exposure to TNB and ethanol is associated with tissue injury.
In the present study, we document that increased synthesis of IL-4 after Ad5IL-4 injection through the peritoneal route had a therapeutic effect in rats experiencing TNB-colitis due, in part, to a reduction in NOS II expression and nitric oxide synthesis. On day 6 postinduction of colitis, rats receiving Ad5IL-4 on day 1 and 3 post-TNB had increased circulating IL-4, decreased circulating IFN- $\gamma$, markedly fewer peritoneal adhesions, significantly less macroscopic damage, and reduced myeloperoxidase (MPO) activity in the distal colon. Ad5IL-4 gene transfer into TNB-inflamed rats also inhibited the induction of NOS II in the colon, as shown by reverse transcription polymerase chain reaction and calcium-independent nitric oxide synthase activity. In contrast, rats treated with the Ad5 control, Ad5LacZ, did not experience any reduction in the severity of colonic inflammation or in NOS II expression and nitric oxide production in the colon. Taken together, these data strongly support an immunomodulatory and antiinflammatory role for IL-4 in experimental colitis and may provide a novel approach for the delivery of immunoregulatory cytokines in IBD.

\section{Methods}

Animals. Specific pathogen-free, male, Sprague-Dawley rats (180200 grams; Charles River Laboratories, Montreal, Canada) were caged in groups of two in a Level B clean room. All rats had ad libitum access to food and water before and during the study. The protocols used were in direct accordance with guidelines drafted by the McMaster University Animal Care Committee and the Canadian Council on the Use of Laboratory Animals.

Materials. Human Ad5 lacking the E1 region of its genome which regulates replication were transfected with murine IL-4 cDNA (Ad5IL-4) or with Escherichia coli Lac Z (Ad5LacZ) according to detailed procedures published elsewhere $(6,8)$. $\beta$-galactosidase activity was determined using an assay system and authentic $\beta$-galactosidase purchased from Promega Corp. (Madison, WI). TNB was purchased from Eastman Kodak Co. (Rochester, NY). The following monoclonal antibodies used in the cytokine ELISAs were purchased from PharMingen (San Diego, CA): rat anti-mouse IL-4 (capture antibody; BVD4-1D11), biotinylated rat anti-mouse IL-4 (detection antibody; BVD6-24G2), purified rat anti-mouse IFN- $\gamma$ (capture antibody; R4-6A2) and biotinylated rat anti-mouse IFN- $\gamma$ (detection antibody; XMG1.2). Nunc-immuno ELISA plates (MaxiSorp ${ }^{\mathrm{TM}}$ ) and recombinant rat IFN- $\gamma$ were obtained from Gibco BRL (Burlington, Canada). Recombinant murine IL-4 (rmIL-4) was obtained from Intermedico (Markham, Canada). NOSdetect ${ }^{\mathrm{TM}}$ assay kits were purchased from PDI BioScience Inc. (Aurora, Canada). Unless otherwise stated, all other materials were purchased from Sigma Chemical Co. (St. Louis, MO).

Induction of colitis. While a mouse model of TNB colitis has recently been described (37), the rat model remains the better described and most frequently used experimental IBD model (38). We also used the rat model of TNB-colitis (25) because the role of nitric oxide in this model has been well established in our laboratory (32) and in others (35). Briefly, each rat $(n=54)$ was lightly anesthetized with Fluothane ${ }^{\mathrm{TM}}$ (halothane b.p.; Wyeth-Ayerst Canada, Inc., Montreal, Canada). $30 \mathrm{mg}$ of TNB dissolved in $0.25 \mathrm{ml}$ of $50 \%$ ethanol was instilled into the distal colon of each animal using a PE-50 cannula (Becton Dickinson Labware, Lincoln Park, NJ) attached to a 1-ml syringe. After instillation, each animal was returned to its respective cage for recovery from anesthesia. Using this procedure, $>95 \%$ of the rats retained the TNB-ethanol enema. However, if an animal quickly (i.e., in $<5 \mathrm{~min}$ ) excluded this solution, it was omitted from the remainder of the study. Control or uninflamed rats $(n=24)$ received normal saline $(0.9 \%$; wt/vol) intracolonically in a similar manner. 
TNB-treated and control rats were kept in separate cages over the course of the study.

Study protocol. Ad5LacZ or Ad5IL-4, both at a concentration of $3.0 \times 10^{6}$ plaque forming units $(\mathrm{PFU}) / \mathrm{ml}$ of HBSS $(\mathrm{pH} 7.4)$, were injected into the peritoneal cavity of uninflamed ( $n=6$ /group) or TNBinflamed ( $n=16 /$ group) rats $1 \mathrm{~h}$ after the enema. $3 \mathrm{~d}$ later, a second injection of Ad5LacZ or Ad5IL-4 (both at $3.0 \times 10^{6} \mathrm{PFU} / \mathrm{ml}$ HBSS) was given to half of the control and TNB-inflamed rats. This route and time course of Ad5 delivery to these animals was based on previous studies. Braciak et al. (6) have shown that an injection of Ad5 expressing luciferase via the peritoneal route resulted in Ad5 infection predominately in the liver (53\% of total) and also in the spleen and peritoneum. Further, because it has also been shown that cytokine production after Ad5-cytokine gene injection into the peritoneal cavity only persists for $4 \mathrm{~d}$ (6), we included groups that received Ad5LacZ or Ad5IL-4 on day 1 and on day 3 of this study. While we have previously shown that Ad5LacZ and Ad5IL-4 can be delivered selectively to the external surface of the intestinal tract (7), we did not use this technique in the present study because of its direct proinflammatory effect on the intestine. On day 6 of the study, all rats were anesthetized with Fluothane ${ }^{\mathrm{TM}} .1 \mathrm{ml}$ of blood was removed by cardiac puncture and transferred to a $1.5-\mathrm{ml}$ centrifuge tube on ice. Immediately after blood removal, rats were killed by cervical dislocation, and the entire length of the colon was excised through a longitudinal peritoneal opening. The colon was immediately placed in phosphate buffered saline, washed with this solution, opened lengthwise, and a macroscopic score was assigned using a previously published macroscopic damage scoring scale (32). The colon and other tissues were processed according to the procedures described below.

In vivo gene transfer: assessment of viral infection by Lac- $Z$ activity. Huard et al. (39) have shown that the route of administration of Ad5 influences the tissue distribution of viral transduction. Thus, the reporter gene LacZ (E. coli galactosidase) was used to demonstrate the presence of Ad5 in various tissues in the peritoneal cavity after ip injection. As previously described (39), the diaphragm, gastrocnemius, liver, and colon were removed from rats on day 6 of the study, and these tissues were homogenized in Reporter Lysis Buffer ${ }^{(B)}$ (Promega Corp.). $\beta$-galactosidase activity was measured as the hydrolysis of $o$-nitrophenyl- $\beta$-D-galactopyranoside to $o$-nitrophenyl (a yellow product) in 96-well plates following a 30-min incubation at $37^{\circ} \mathrm{C}$. Enzyme activity was calculated from sample absorbencies using an authentic $\beta$-galactosidase standard curve. Other samples of the same tissues were fixed with $2 \%$ paraformaldehyde for $5 \mathrm{~min}$ and $\beta$-galactosidase activity in Ad5LacZ-injected rats was assessed after exposure of these tissues to the chromogen 5-bromo-4-chloro- $\beta$-D-galactopyranoside (X-gal; Boehringer Mannheim, Indianapolis, IN). Briefly, the tissues were placed into phosphate buffered saline containing X-gal $(0.5 \mathrm{mg} / \mathrm{ml})$, potassium ferricyanide $(5 \mathrm{mM})$, potassium ferrocyanide $(5 \mathrm{mM})$, and magnesium chloride $(2 \mathrm{mM})$, and these samples were incubated overnight at $37^{\circ} \mathrm{C}$. Samples were processed using routine histological techniques and embedded in paraffin. $5-\mu \mathrm{m}$ sections of colon were lightly stained with hemotoxylin and eosin.

Measurement of serum and colon IL-4 and IFN- $\gamma$ levels. Murine IL-4 and rat IFN- $\gamma$ levels were determined in $50 \mu \mathrm{l}$ serum or colon homogenate samples collected from rats on day 6 of the study using a standardized sandwich ELISA protocol from PharMingen. A 200300 -mg section of full-thickness colon was removed from all TNBinflamed rats $\sim 6 \mathrm{~cm}$ from the anal margin. These samples were homogenized in $2 \mathrm{ml}$ of protease inhibitor cocktail, and centrifuged at $3,000 \mathrm{~g}$ for $10 \mathrm{~min}$. ELISA plates were coated with the appropriate cytokine capture antibody (see Materials above) at a dilution of $2 \mu \mathrm{g} /$ $\mathrm{ml}$ of tris-buffered saline (TBS) containing bovine serum albumin (BSA; $10 \mathrm{mg} / \mathrm{ml}$ ) for $24 \mathrm{~h}$ at $4^{\circ} \mathrm{C}$. The capture antibodies were subsequently removed and each plate was blocked for $24 \mathrm{~h}$ with TBS-BSA at $4^{\circ} \mathrm{C}$. After the blocking period, each ELISA plate was washed with TBS-BSA containing Tween-20 (0.05\%; vol/vol), and experimental samples were added to wells in triplicate. $24 \mathrm{~h}$ later, the plates were thoroughly washed and the appropriate detection antibody $(500 \mathrm{ng} /$ $\mathrm{ml}$ TBS-BSA) was added for $3 \mathrm{~h}$. Streptavidin-alkaline phosphatase (1:20,000 dilution) was added to each washed well for $2 \mathrm{~h}$, and each plate was thoroughly washed again. An ELISA amplification system (Gibco BRL) was used to increase the amount of color generated per quantity of immobilized streptavidin-alkaline phosphatase. The monoclonal antibodies directed against murine IL-4 did not cross react with rat IL-4, thus we were able to specifically determine the amount of murine IL-4 produced after Ad5IL-4 injection into rats. A rmIL-4 standard curve was used to calculate IL-4 serum levels in all Ad5infected rats. In contrast, the monoclonal antibodies used to capture and detect IFN- $\gamma$ did cross-react with rat IFN- $\gamma$ and thus, a rat IFN- $\gamma$ standard curve was used to calculate IFN- $\gamma$ serum levels.

Assessment of colonic myeloperoxidase activity. Tissues (200-400 $\mathrm{mg}$ ) for determination of MPO activity were removed from the area of gross injury (i.e., $4-6 \mathrm{~cm}$ proximal to the anus) and snap frozen in liquid nitrogen. MPO is an enzyme located in neutrophils, eosinophils, and other cells of myeloid origin, and measures of MPO activity are commonly used as a marker of intestinal inflammation (38). MPO activity in samples of control and TNB-treated distal colon from Ad5treated rats was determined using a previously published method (32). Briefly, samples were thawed, weighed, and homogenized in hexadecyltrimethyl-ammonium bromide buffer. These homogenates were centrifuged and MPO activity was measured in the supernatants. MPO was expressed as units/milligram of tissue where $1 \mathrm{U}$ corresponds to the activity of enzyme required to degrade $1 \mu \mathrm{mol}$ of hydrogen peroxide in a minute at $24^{\circ} \mathrm{C}$.

Detection of inducible nitric oxide synthase by reverse transcriptase $P C R$. On day 6 of the study, samples of colon for mRNA isolation were removed $6 \mathrm{~cm}$ proximal to the anus in control rats or from the upper margin of the grossly damaged distal colon in the TNB-inflamed rats. Total cellular RNA was isolated using a previously described guanidium isothiocyanate method (40). The concentration of RNA was determined by absorbance at $260 \mathrm{~nm}$ and its purity was confirmed using the ratio of absorbency at $260 \mathrm{~nm}$ to that at $280 \mathrm{~nm}$. RNA was stored at $-70^{\circ} \mathrm{C}$ until used for reverse transcription-polymerase chain reaction (RT-PCR). mRNA was next reverse transcribed as previously described (40) to yield cDNA. 2- $\mu$ l aliquots of cDNA $(3 \mu \mathrm{g})$ were then mixed with 20 pmol each of sense $\left(5^{\prime}\right.$-TTC CGA AGT TTC TGG CAG-3') and antisense (5'-ATA GGA AAA GAC TGC ACC GAA GAT-3') primers for NOS II (41). The positive control used in the PCR reaction was $\beta$-glucuronidase, and 20 pmol each of sense primer (5'-GTG ATG TGG TCT GTG GCC AA-3') and anti-sense primer (5'-TCT GCT CCA TAC TCG CTC TG-3') were used to detect it (42). PCR was completed in $50 \mu \mathrm{l} \mathrm{vol-}$ umes containing dNTP $(200 \mu \mathrm{M}), \mathrm{Mg}^{2+}(1.5 \mathrm{mM}), 2.5 \mathrm{U}$ Taq polymerase (Gibco BRL) with corresponding buffer and distilled water. NOS II and $\beta$-glucuronidase were coamplified for 33 cycles using the following cycle parameters: denaturation $94^{\circ} \mathrm{C}$ for $30 \mathrm{~s}$, annealing $57^{\circ} \mathrm{C}$ for $30 \mathrm{~s}$, and extension at $72^{\circ} \mathrm{C}$ for $60 \mathrm{~s}$. PCR products were loaded onto a $2.5 \%$ agarose gel with a $10 \mathrm{X}$ loading buffer, and then visualized under ultraviolet light after ethidium bromide staining. The 500-bp product corresponds to NOS II and the 302-bp product corresponds to $\beta$-glucuronidase.

Assessment of nitric oxide synthase activity. Nitric oxide synthase activity in control and TNB-inflamed colonic tissue was directly determined in Ad5-infected groups ( $n=3$ /group) using an L-citrulline assay (32). L-citrulline is a coproduct of nitric oxide synthesis, and it is formed from L-arginine in a 1:1 stoichimetric reaction. On day 6 full thickness tissues from the distal one third of the colon $(\sim 4-6 \mathrm{~cm}$ of tissue) were homogenized, and supernatants of the homogenates were incubated with tritiated $\left(\left[{ }^{3} \mathrm{H}\right]\right)$-L-arginine (Amersham, Arlington Heights, IL) and cofactors NADPH, FAD, FMN and $\mathrm{BH}_{4}$ for 60 min at $37^{\circ} \mathrm{C}$ in the absence of $\mathrm{CaCl}_{2}$. To ensure that $\mathrm{L}$-citrulline formation was a consequence of nitric oxide generation, identical colonic homogenates with cofactors were incubated in the presence of $\mathrm{N} \omega$-nitro-L-arginine methyl ester $\mathrm{HCl}$ (L-NAME; $1 \mathrm{mM})$. [ $\left[{ }^{3} \mathrm{H}\right]$-L-citrulline was eluted from columns containing an equilibrated resin. Using this procedure, $\sim 90-95 \%$ of the $\left[{ }^{3} \mathrm{H}\right]$-L-citrulline and $<1 \%$ of the 
Table I. $\beta$-galactosidase Activity in Control and TNB-inflamed Rats on Day 6 after One or Two Intraperitoneal Injections of Ad5LacZ

\begin{tabular}{lcclll}
\hline & \multicolumn{2}{c}{ Control groups } & & \multicolumn{2}{c}{ TNB-colitis groups } \\
\cline { 2 - 3 } \cline { 6 - 7 } Tissue site & One dose Ad5 & Two doses Ad5 & & One dose Ad5 & Two doses Ad5 \\
\hline Injection site & $0.228 \pm 0.036$ & $0.181 \pm 0.009$ & & $0.209 \pm 0.001$ & $0.350 \pm 0.040$ \\
Diaphragm & $0.436 \pm 0.010$ & $0.552 \pm 0.019$ & & $0.575 \pm 0.021$ & $0.397 \pm 0.063$ \\
Liver & $4.989 \pm 0.217$ & $4.160 \pm 0.171$ & & $3.400 \pm 0.186$ & $5.280 \pm 0.094$ \\
Colon* & 0 & $0.166 \pm 0.025$ & 0 & $0.076 \pm 0.032$
\end{tabular}

* $\beta$-galactosidase values were corrected for endogenous $\beta$-galactosidase activity from bacteria located in the lumen of the colon. $\beta$-galactosidase activity (milliunits) was measured in tissue homogenates of the intraperitoneal injection site, liver, diaphragm, and colon as described in the Methods section. Data represent mean \pm SEM of three rats per injection group.

$\left[{ }^{3} \mathrm{H}\right]$-L-arginine was recovered. Therefore, background counts from the trace amounts of $\left[{ }^{3} \mathrm{H}\right]-\mathrm{L}$-arginine were subtracted from the counts of each sample before calculation of the total nitric oxide synthase activity in the homogenates. After the determination of protein in the tissue homogenates according to Lowry et al. (43), nitric oxide synthase enzyme activity was calculated using the following formula: adjusted counts $(\mathrm{dpm} /$ gram of protein $) \times 63.1 \mathrm{Ci} \mathrm{mmol}^{-1}(\mathrm{sp}$ act $) / 2.22 \times$ $10^{6} \mathrm{~min}^{-1}$ (conversion rate) $\times 60 \mathrm{~min}$.

Data analysis. All data are expressed as mean \pm SEM; $n$ refers to the quantity of animals. Statistical analysis was calculated using oneway ANOVA, and multiple comparisons were performed using the Newman-Keuls multiple comparison test. An associated probability of $\leq 5 \%$ was indicated as significant.

\section{Results}

$\beta$-galactosidase activity in Ad5LacZ-injected rats. To confirm that Ad5 infection was successful in control and TNB-inflamed rats and determine the relative tissue distribution of virus, Ad5 containing LacZ were injected intraperitoneally into control and colitic rats. The peritoneal lining, diaphragm, liver, and co- lon from Ad5LacZ-infected control and colitic rats were examined for $\beta$-galactosidase activity, and as shown in Table I, $\beta$-galactosidase activity was present in all tissues examined. No background $\beta$-galactosidase activity was measured in the peritoneal lining, diaphragm, or liver of noninfected rats from either inflammation group, but constitutive expression of this enzyme was present in colon samples taken from the same rats (not shown). The greatest expression of $\beta$-galactosidase activity after Ad5LacZ injection was observed in liver biopsies from control and colitic animals (Table I). Consistent increases in $\beta$-galactosidase activity between the groups that received one vs two injections of Ad5LacZ were not observed in the injection site, diaphragm, or liver. However, when corrected for endogenous bacterial $\beta$-galactosidase activity, clear increases in $\beta$-galactosidase activities were observed in colonic tissue taken from rats injected twice with Ad5LacZ when compared with $\beta$-galactosidase activity in colons removed from rats injected once with Ad5LacZ. These data suggested that TNBcolitis did not impair the ability of Ad5 to infect various tissues in the rat, and also showed that two injections of virus were associated with detectable infection of distal colon.

Circulating IL-4 levels are increased after intraperitoneal Ad5IL-4 gene transfer. Further confirmation of Ad5 infection and transduction in control and TNB-inflamed rats was determined through the use of a murine IL- 4 sandwich ELISA for the measurement of serum IL-4. The murine mAbs used to detect serum mIL-4 did not cross-react with rat recombinant IL-4 (not shown). On day 6 of the study, no IL- 4 was detected in either group of control or TNB-inflamed rats injected with Ad5LacZ (Fig. 1, $A$ and $B$ ). However, as summarized in Fig. 1, $A$ and $B$, control and TNB-inflamed rats that received Ad5IL-4 had measurable amounts of immunoreactive serum IL-4. Control rats injected once with Ad5IL-4 had $1.2 \pm 0.47 \mathrm{ng} \mathrm{mIL}-4 / \mathrm{ml}$ of serum and two doses of Ad5IL-4 augmented levels of IL-4 to $2.3 \pm 1.24 \mathrm{ng} / \mathrm{ml}$. In rats with TNB-colitis, serum levels of IL-4 were about threefold higher in animals that received one dose of Ad5IL-4 compared with rats that received two doses of Ad5IL-4 (9.3 \pm 2.7 vs $3.0 \pm 2.3 \mathrm{ng} \mathrm{mIL}-4 / \mathrm{ml}$ serum).

Numerous studies of therapeutic interventions in experimental and clinical IBD have shown the importance of mea-
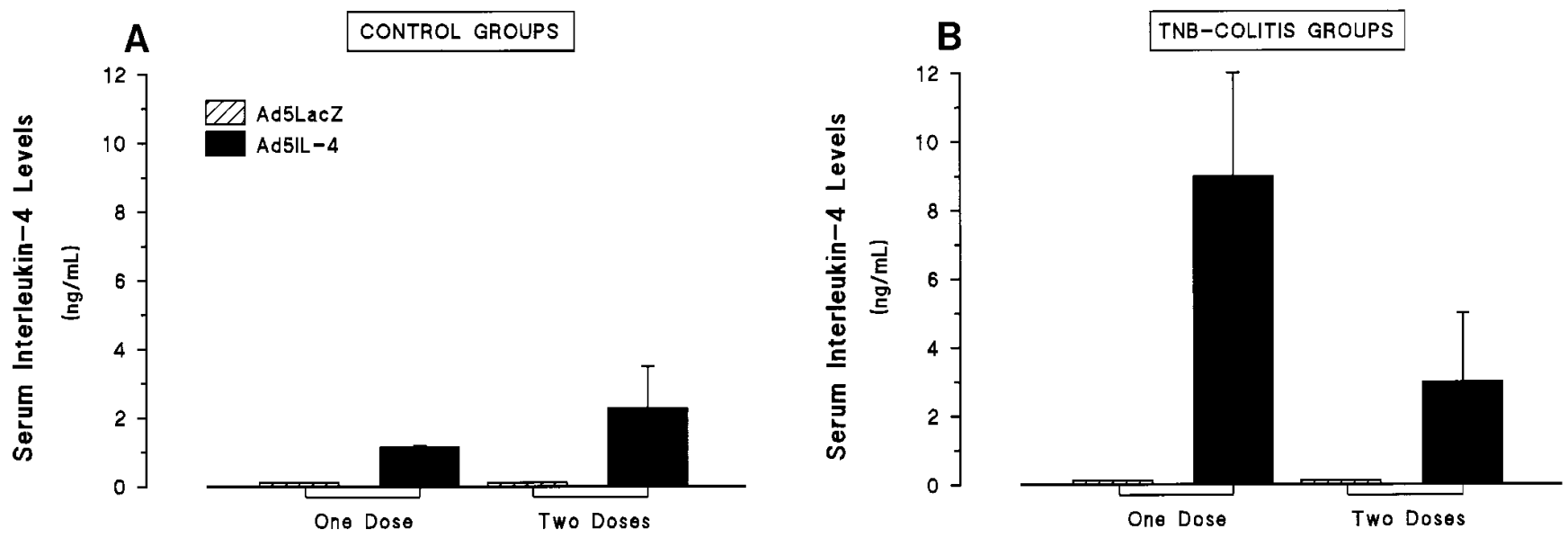

Figure 1. Serum IL-4 levels in control $(A)$ and colitic rats $(B)$ on day 6. All rats received Ad5LacZ or Ad5IL-4 $1 \mathrm{~h}$ after the start of the study or after the induction of TNB colitis. On day 3, half of the rats were injected again (i.e., two doses) with Ad5LacZ or Ad5IL-4. Data shown represent the quantity of circulating IL-4 measured using a murine ELISA (see Methods section) and are mean \pm SEM of 6-8 rats per dosing group. 


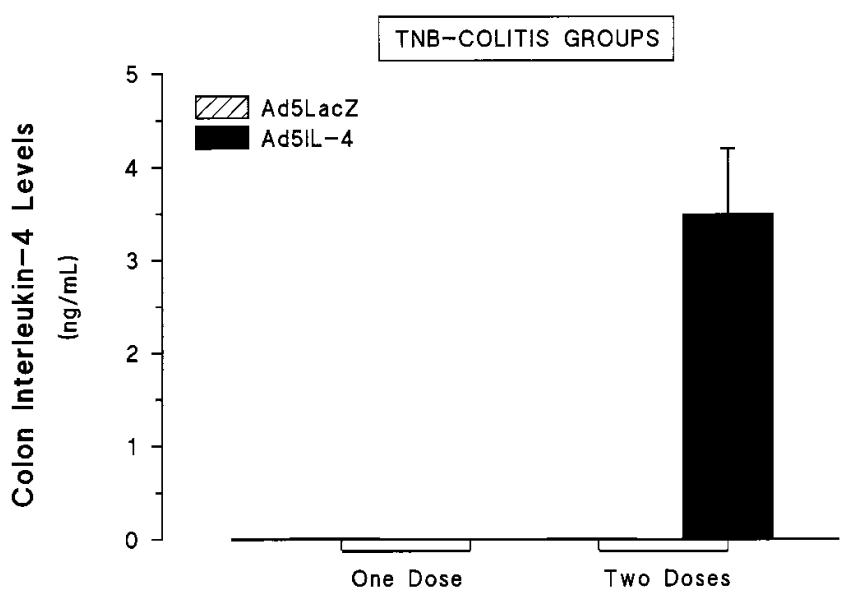

Figure 2. Colon IL-4 levels in rats on day 6 after TNB administration. All rats received Ad5LacZ or Ad5IL-4 $1 \mathrm{~h}$ after the intrarectal injection of TNB colitis. On day 3 , half of the rats were injected again (i.e., two doses) with Ad5LacZ or Ad5IL-4. Data shown represent the quantity of IL-4 measured in supernatants from colon homogenates $(100 \mathrm{mg} / \mathrm{ml})$ using a murine ELISA (see Methods section) and are mean \pm SEM of $6-8$ rats per dosing group. $* P \leq 0.05$ compared with double-injected Ad5LacZ rats with TNB colitis.

suring changes in cytokine levels in intestinal tissue. These studies have highlighted that systemic changes in cytokine levels do not necessarily mirror alterations in these mediators at the site of intestinal inflammation. Although one injection of Ad5IL-4 in TNB-colitis rats gave the higher levels of serum IL-4, only the dual intraperitoneal injection of Ad5IL-4 was associated with detectable quantities of immunoreactive mIL-4 $(3.5 \pm 0.7 \mathrm{ng} / \mathrm{ml})$ in the distal colon (Fig. 2).

Ad5IL-4 reduces circulating and colon IFN- $\gamma$ levels in TNB-treated rats. Elevations in IFN- $\gamma$ have recently been described in a murine TNB-colitis model (37) and in the $\mathrm{CD}_{45 \mathrm{RB}^{\text {hi }}} \mathrm{T}$ cell reconstitution colitis model (18). Further, resolution of colitis in both models is associated with a pronounced reduction in IFN- $\gamma$ synthesis $(27,37)$. In the present

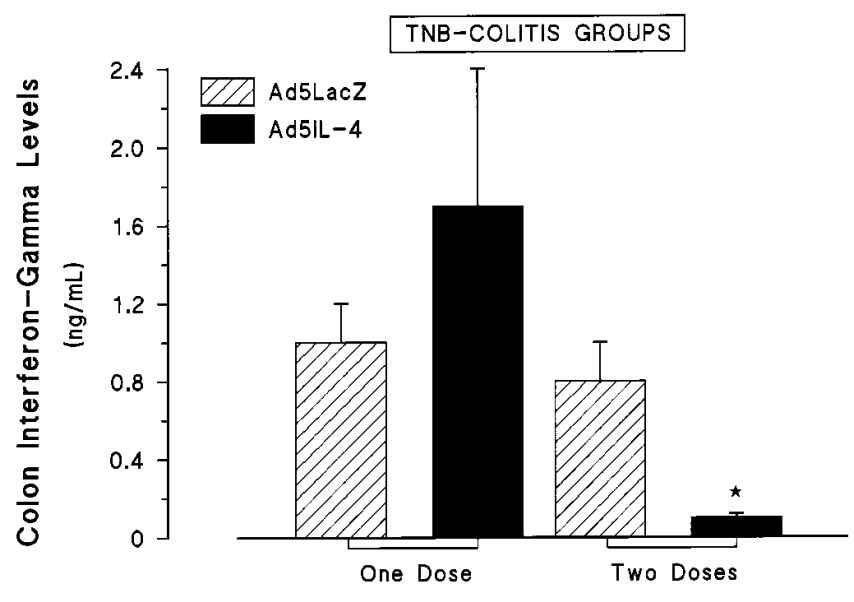

Figure 4. Colon IFN- $\gamma$ levels in colitic rats on day 6 . All rats received Ad5LacZ or Ad5IL-4 $1 \mathrm{~h}$ after the intrarectal administration of TNB. On day 3, half of the rats were injected again (i.e., two doses) with Ad5LacZ or Ad5IL-4. Data shown represent mean \pm SEM of 6-8 rats per dosing group $* P \leq 0.05$ compared with double-injected Ad5LacZ rats with TNB colitis.

study, IFN- $\gamma$ was detected in a standard sandwich ELISA using murine anti-IFN- $\gamma$ antibodies (i.e., capture and detection) that cross-reacted with rat IFN- $\gamma$. The cross-reactivity of these mAbs was confirmed using recombinant rat IFN- $\gamma$ as a standard in each ELISA assay. Levels of circulating IFN- $\gamma$ were typically present at the lower limit of detection in this ELISA (i.e., $\sim 10 \mathrm{pg} / \mathrm{ml}$ ). Administration of Ad5LacZ did not affect the amount of immunoreactive IFN- $\gamma$ present in the control groups (Fig. $3 A$ ). However, control rats that were injected with one dose of Ad5IL-4 had levels of IFN- $\gamma$ exceeding $5 \mathrm{ng} /$ $\mathrm{ml}$ (Fig. $3 A$ ) while control rats that were injected twice with the same Ad5 expressed $3 \pm 1 \mathrm{ng}$ IFN- $\gamma / \mathrm{ml}$ of serum. Marked elevations in IFN- $\gamma$ were observed in TNB-inflamed rats (Fig. $3 \mathrm{~B})$. Neither of the Ad5LacZ treatment groups (35 \pm 10 and $24 \pm 12 \mathrm{ng}$ IFN $-\gamma / \mathrm{ml}$ of serum, respectively) nor the Ad5IL-4 group that received a single injection $(28 \pm 8 \mathrm{ng}$ IFN- $\gamma / \mathrm{ml}$ of se-
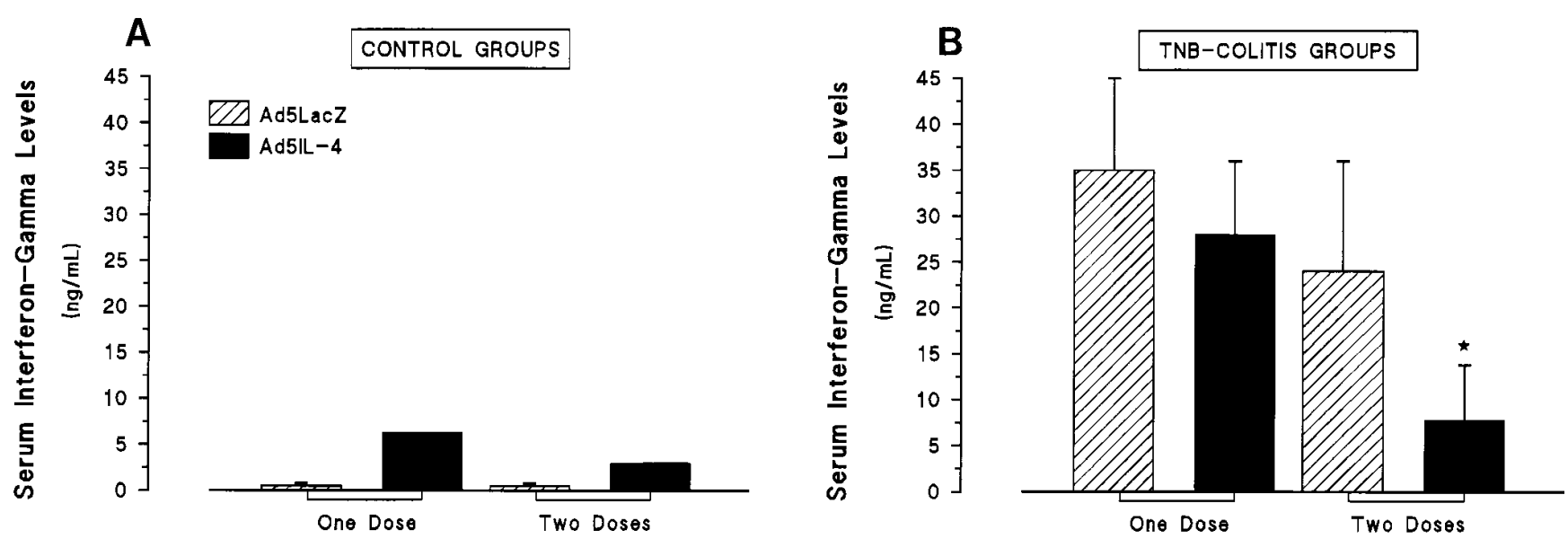

Figure 3. Serum IFN- $\gamma$ levels in control $(A)$ and colitic rats $(B)$ on day 6. All rats received Ad5LacZ or Ad5IL-4 $1 \mathrm{~h}$ after the start of the study or after the induction of colitis. On day 3, half of the rats were injected again (i.e., two doses) with Ad5LacZ or Ad5IL-4. Data shown represent mean \pm SEM of 6-8 rats per dosing group. ${ }^{*} P \leq 0.05$ compared with double-injected Ad5LacZ rats with TNB colitis. 
rum) had circulating levels of IFN- $\gamma$ that differed significantly from uninfected TNB rats $(49 \pm 15 \mathrm{ng}$ IFN $-\gamma / \mathrm{ml}$ of serum; not shown). However, in rats that received two doses of Ad5IL-4, circulating IFN- $\gamma$ levels were reduced to $9 \pm 5 \mathrm{ng} / \mathrm{ml}$.

Immunoreactive levels of IFN- $\gamma$ in colonic homogenates from TNB-colitic rats are shown in Fig. 4. In colitic rats that received one or two injections of Ad5LacZ, IFN- $\gamma$ levels were $\leq 1.0 \mathrm{ng} / \mathrm{ml}$. However, in colitic rats that received one dose of Ad5IL-4, IFN- $\gamma$ levels approached $2.0 \mathrm{ng} / \mathrm{ml}$ (Fig. 4). Colonic levels of IFN- $\gamma$ were significantly decreased in colitic rats that received two injections of Ad5IL-4 (Fig. 4), consistent with the decreases in circulating IFN- $\gamma$ in these rats.

Two intraperitoneal injections of Ad5IL-4 markedly attenuates macroscopic and microscopic injury in TNB-colitis. Examination of the peritoneal cavity in a rat with acute (i.e., on day 6) TNB colitis characteristically reveals multiple adhesions between the colon and other organs, and a markedly dilated and thickened distal colon (32). A view of the mucosal surface of the colon typically revealed frank ulceration, particularly in the area of the colon exposed initially to the TNB and ethanol enema. In the present study, we saw no deviation from this macroscopic picture in colitic rats treated with Ad5LacZ. Out of a total macroscopic damage score of 10, damage scores in these groups were $7 \pm 1$ and $8 \pm 2$, respectively, and these values were similar to those obtained previously in noninfected TNBtreated rats (32). Intraperitoneal injection of control rats with one or two doses of Ad5LacZ (not shown) or Ad5IL-4 had no effect on the macroscopic appearance of the colon. Rats that received one ip injection of Ad5IL-4 exhibited distal colonic injury similar to that seen in the Ad5LacZ-treated groups with a macroscopic damage score of $6 \pm 3$. However, in rats injected twice with Ad5IL-4 there was a marked improvement in the macroscopic picture, and this was reflected in a significantly lower macroscopic injury score of $3 \pm 1$. Also in contrast to the other treatment groups, no adhesions between the colon and other organs in the peritoneal cavity were evident. The therapeutic effect of two peritoneal injections of Ad5IL-4 was confirmed by a histologic examination of tissues from the distal colon of TNB-treated rats. While transverse sections of distal colon revealed marked transmural injury in tissues from the other three Ad5-injected groups, an intact colonic architecture and an absence of neutrophil infiltration were observed in the double-injected Ad5IL-4 group. Fig. 5, $A-H$ illustrates the histologic appearance of the colon in each of the Ad5 treatment groups. As shown in the first four panels of Fig. 5, nothing abnormal was observed in colon samples taken from Ad5-injected control rats. After $6 \mathrm{~d}$ of colitis the microscopic picture of the colon was vastly different. Note the presence of deep penetrating ulcers and the marked infiltrate characterized by neutrophils, eosinophils and lymphocytes in the Ad5LacZ groups (Fig. 5, $E$ and $F$ ) and the single injection Ad5IL-4 group (Fig. 5 $G)$. Fig. $5 H$ illustrates the characteristic appearance of colonic tissues removed from colitic rats that received two injections of Ad5IL-4. A marked reduction in tissue injury and inflammatory cell infiltrates was readily apparent in all sections of colon examined from these rats.

Granulocyte accumulation in TNB-treated colon is inhibited by Ad5IL-4 treatment. Administration of Ad5LacZ or Ad5IL-4 to control rats did not affect MPO activity in the distal colon (Fig. 6 A). Similar to the histologic observations, two injections of Ad5IL-4 in TNB-colitis rats significantly reduced by approximately threefold the amount of MPO activity in the distal colon (Fig. 6 B). However, MPO activity in this Ad5-injected TNB group was still elevated above those observed in the controls.

Ad5IL-4 gene transfer inhibits NOS II gene expression and colonic nitric oxide synthesis. Fig. 7 illustrates the expression of NOS II and $\beta$-glucuronidase in the four Ad5-infected groups examined in this study. Although $\beta$-glucuronidase gene expression was present in all RNA samples subjected to RT-PCR, NOS II was absent in all control colonic samples from Ad5LacZ- and Ad5IL-4-injected rats. In contrast, NOS II gene expression was apparent in all colonic tissues removed from TNB-inflamed rats, but NOS II gene expression was diminished in colon samples removed from rats injected twice with Ad5IL-4 (Fig. 7). Colonic calcium-independent or NOS II nitric oxide synthesis, as determined by the measurement of $\left[{ }^{3} \mathrm{H}\right] \mathrm{L}$-citrulline formation in colonic homogenates without exogenous $\mathrm{CaCl}_{2}$, was $<10 \mathrm{nmol} / \mathrm{min}$ per gram of protein in control rats injected twice with Ad5LacZ (Fig. 8). Two injections of Ad5IL-4 in control rats reduced colonic nitric oxide synthesis approximately fivefold. On day 6 after TNB administration and after two injections of Ad5LacZ, NOS II nitric oxide synthesis was increased fivefold (Fig. 8). The increase in NOS II activity observed here was similar to those reported previously in the TNB colitis model $(32,35)$. In rats injected twice with Ad5IL-4, NOS II nitric oxide synthesis was significantly reduced by $\sim 50 \%$. The presence of L-NAME during the 60 -min reaction reduced nitric oxide synthase activity to levels observed in Ad5LacZ-injected, control rats (Fig. 8).

\section{Discussion}

The present study demonstrates that increased in vivo IL-4 levels through Ad5 gene delivery had a marked therapeutic effect in an acute model of experimental colitis. Every parameter examined indicated that a dual treatment of rats with Ad5IL-4 resulted in significantly reduced amounts of circulating and tissue IFN- $\gamma$, and in a significant improvement in the histologic appearance of the distal colon. Further, the reduction in distal colonic injury was associated with a decrease in NOS II gene expression and calcium-independent nitric oxide synthesis in the colon. The delivery of Ad5IL-4 to rats allowed us to directly determine the in vivo therapeutic effect of IL-4 in a well-characterized model of distal colonic inflammation. While there is concern about an immune response mounted against a foreign murine protein (44) and the Ad5 vector itself (45), these studies were acute (i.e., $6 \mathrm{~d}$ ) in duration permitting a rather limited immune response by the rats to these elements. Further, the rat model of TNB-colitis provides many advantages over the murine model recently described $(37,46)$. The intestinal injury in rat TNB-colitis is mediated almost exclusively by infiltrating neutrophils (47), the deleterious role of increased nitric oxide synthesis in this model is well characterized $(32,35)$, and rats with TNB colitis respond to many of the therapies currently used in the clinical treatment of IBD (26). Taken together, these findings illustrate that immunoregulatory cytokines may have utility in the treatment of inflammatory diseases of the bowel.

Why use a strategy of cytokine gene delivery by Ad5 rather than the direct delivery of recombinant cytokine? The use of an Ad5 vector offers many advantages over the bolus delivery of recombinant cytokine. For a study extending $>6 \mathrm{~d}$ in rats the amounts of recombinant cytokine required would be pro- 
A

Q.1.
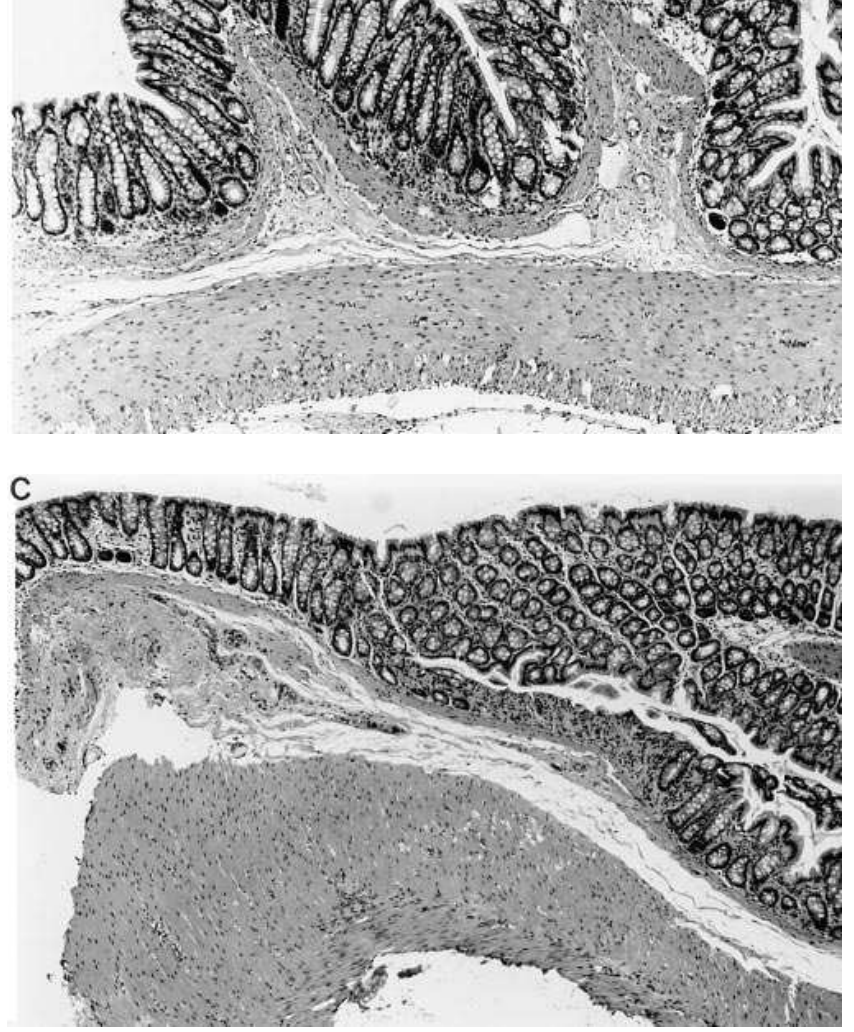

E
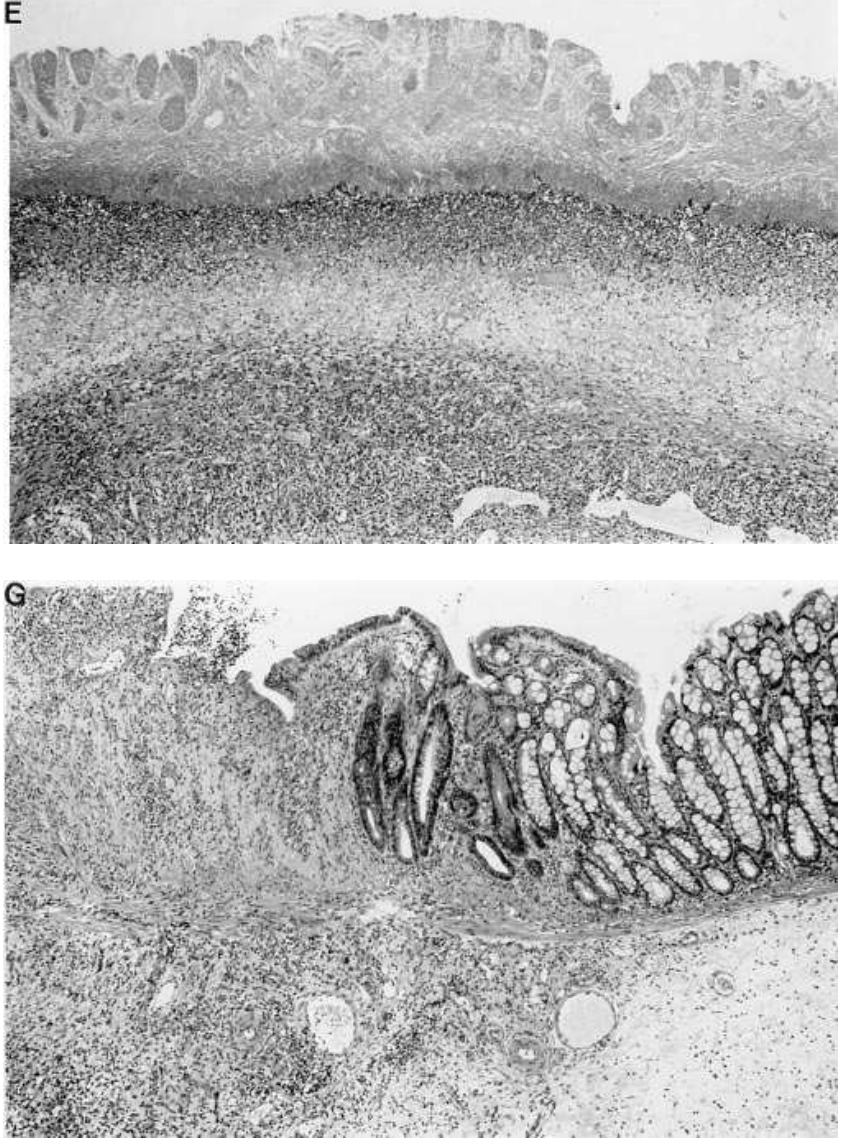

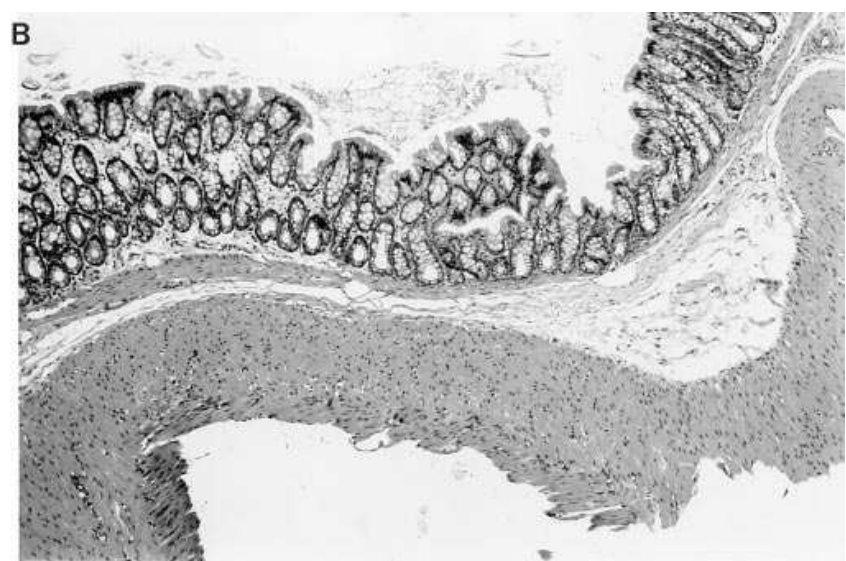

D
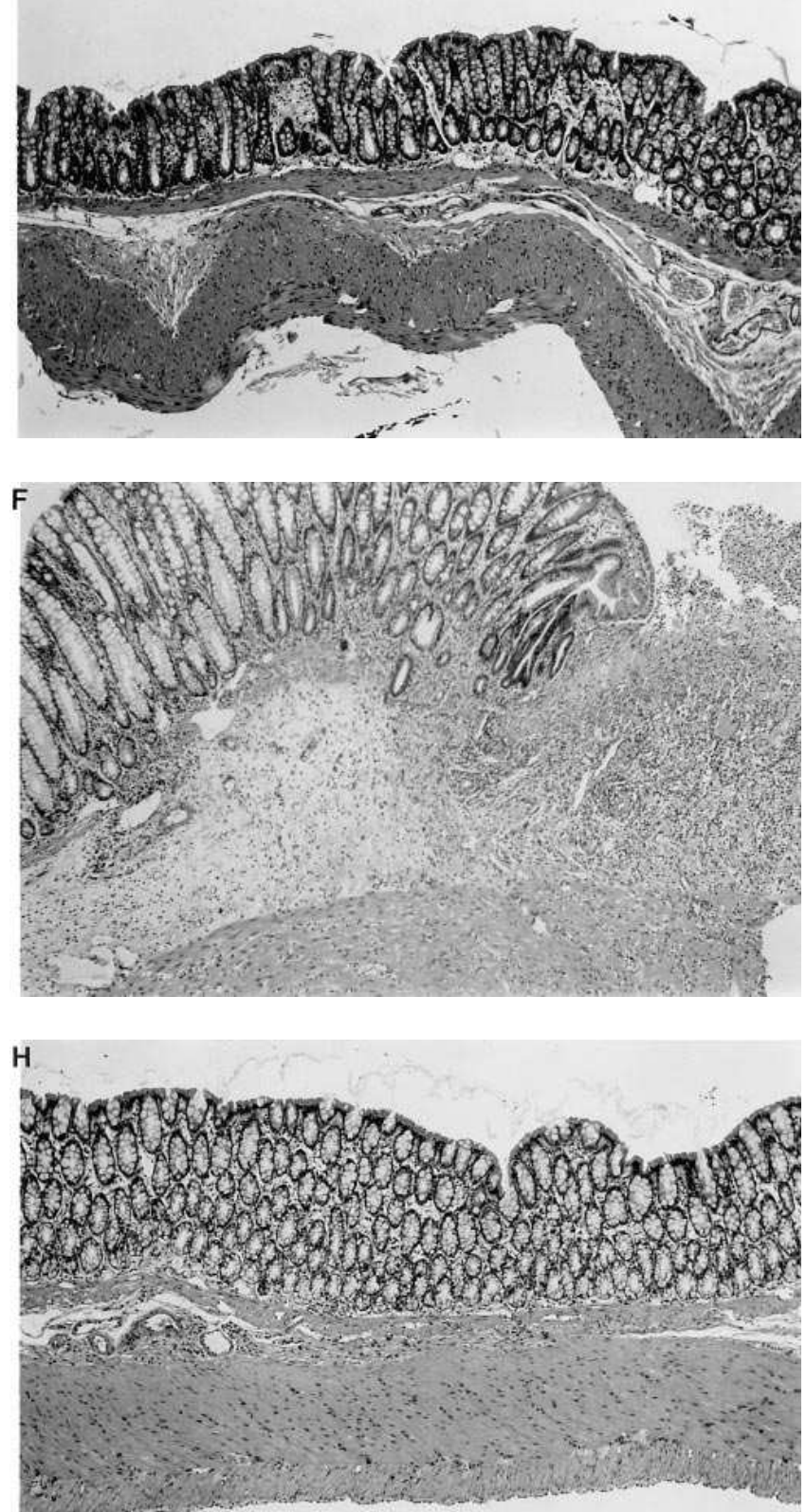

Figure 5 

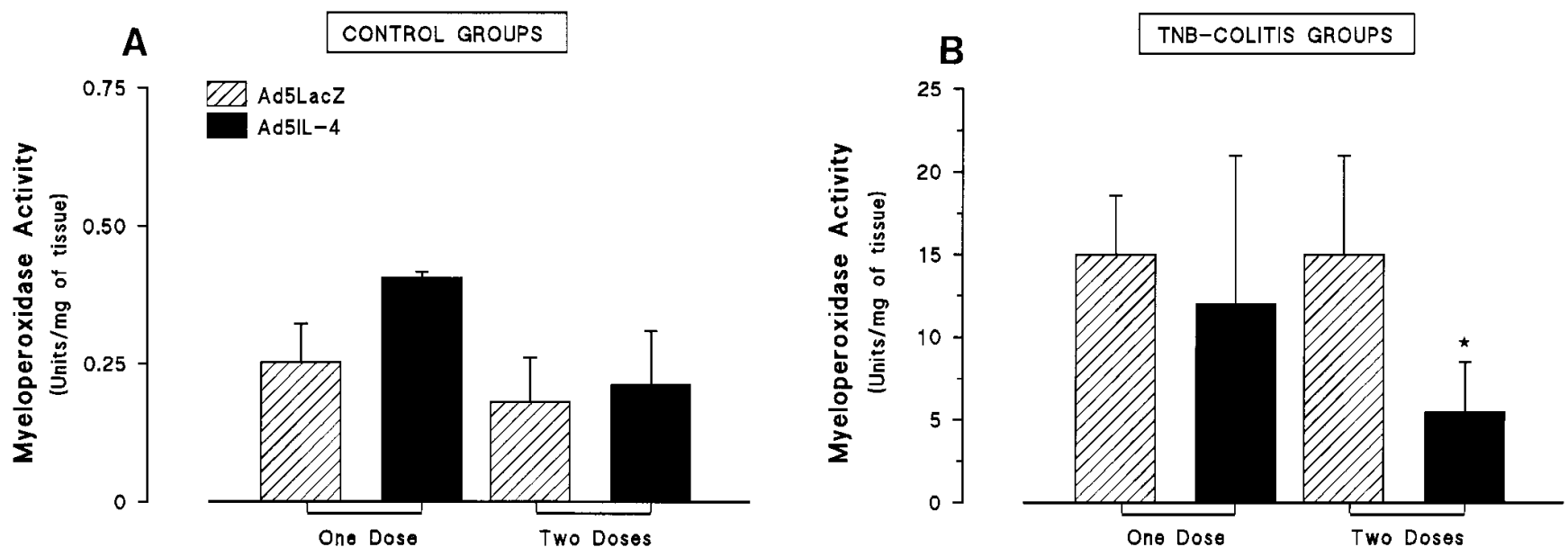

Figure 6. Myeloperoxidase (MPO) activity in colon samples from control $(A)$ and colitic rats $(B)$ on day 6 . All rats received Ad5LacZ (hatched bars) or Ad5IL-4 (solid bars) $1 \mathrm{~h}$ after the start of the study or after the induction of colitis. On day 3, half of the rats were injected again (i.e., two doses) with Ad5LacZ or Ad5IL-4. Data represent mean \pm SEM of 6-8 rats per dosing group. $* \leq \leq 0.05$ compared with double-injected Ad5LacZ rats with TNB colitis.

hibitively expensive. Further, recombinant cytokines are rapidly cleared from the circulation resulting in a marked fluctuation in the amount of the biologically active cytokine over the course of a study. In contrast, the quantity of cytokine synthesized after Ad5 infection can be regulated by the titer of virus delivered and by the route of Ad5 administration (39). Using Ad5-based gene delivery techniques it has been shown that transitory gene replenishment, vaccination, modulation of cell proliferation, and cytokine delivery is possible (see reference 4 for review). Although previous studies using recombinant Ad5 expressing cytokines have shown the potential pathological role of cytokine over expression in the lung and intestinal tract (6-8), this technique has also demonstrated therapeutic potential in disease processes such as cancer (9). The present study further emphasized the importance of elucidating the therapeutic dose and timeframe of Ad5IL-4 administration. The therapeutic effects of a relatively small amount of adenovirus (i.e., $3.0 \times 10^{6}$ ) were only apparent when delivered in two separate injections $3 \mathrm{~d}$ apart, and these effects appeared to be related to the overexpression of IL- 4 in the colon. Although one injection of Ad5IL-4 resulted in levels of circulating IL-4 that exceeded $8 \mathrm{ng} / \mathrm{ml}$, this increase in IL- 4 was not sufficient to alter the inflammatory (i.e., IFN- $\gamma$ levels and MPO activity) and histologic parameters in this model of colitis. It is not readily apparent why circulating levels of IL-4 in colitic rats injected once with Ad5IL-4 were eightfold higher than levels of control rats that received a similar amount of adenovirus. However, these findings may be related, in part, to the effect of elevated IFN- $\gamma$ on factors that regulate the transcription and/or translation of the IL-4 transgene. Since considerable evidence has accumulated showing that Th1-type (i.e., T cell responses charac- terized by IFN- $\gamma$ synthesis) and Th2-type responses (i.e., T cell responses characterized by IL- 4 synthesis) cross-regulate one another (47), further examination of in vivo regulation of IL-4 and IFN- $\gamma$ during transgene manipulation in colitis is certainly warranted.

Careful attention has been directed at identifying strategies to limit the inflammatory response and immune dysregulation during IBD. Toward this goal, progress has been made in understanding the role of cell-mediated immune responses in the intestinal mucosal lies in the maintenance of cytokine homeostasis, particularly related to those cytokines involved in $\mathrm{T}$ cell function. Gene knock-out murine models of spontaneous IBD (48) have given important clues as to regulation of mucosal immune system, and demonstrate that an imbalance in the $\mathrm{T}$ cell response to cytokine signals in the intestinal tract has deleterious consequences. In gene-competent rodents with experimentally induced IBD, recent findings support a therapeutic role for anticytokine antibodies or recombinant immunomodulatory cytokines. Neurath et al. (37) found that monoclonal antibodies directed against murine IL-12 abrogated established TNB-colitis in mice, and that this therapeutic effect was associated with a marked reduction in the synthesis of Th1 cytokines (i.e., IFN- $\gamma$ and IL-2) in vitro. These observations coincide with those in the present study, in that resolution of colitis following two injections of Ad5IL-4 was associated with a marked reduction in circulating IFN- $\gamma$ levels. Herfath et al. (49) injected recombinant murine IL-10 (rmIL-10) into rats with granulomatous colitis, and observed a beneficial effect of this treatment after $17 \mathrm{~d}$. Rats receiving rmIL-10 had significantly decreased macroscopic damage scores in the colon, liver and joints, and decreased gene expression for IL-1, IL-6,

Figure 5. Histologic appearance of colons removed from control $(A-D)$ and colitic rats $(E-H)$ on day 6 of the study. $(A)$ control rat that received one dose of Ad5LacZ. $(B)$ control rat that received two doses of Ad5LacZ. $(C)$ control rat that received one dose of Ad5IL-4. $(D)$ control rat that received two doses of Ad5IL-4. (E) TNB-treated rat that received one dose of Ad5LacZ. $(F)$ TNB-treated rat that received two doses of Ad5LacZ. $(G)$ TNB-treated rat that received one dose of Ad5IL-4. $(H)$ TNB-treated rat that received two doses of Ad5IL-4. Note the lack of mucosal injury in this Ad5IL-4 treatment group. Original magnification for each panel was 40. 
A
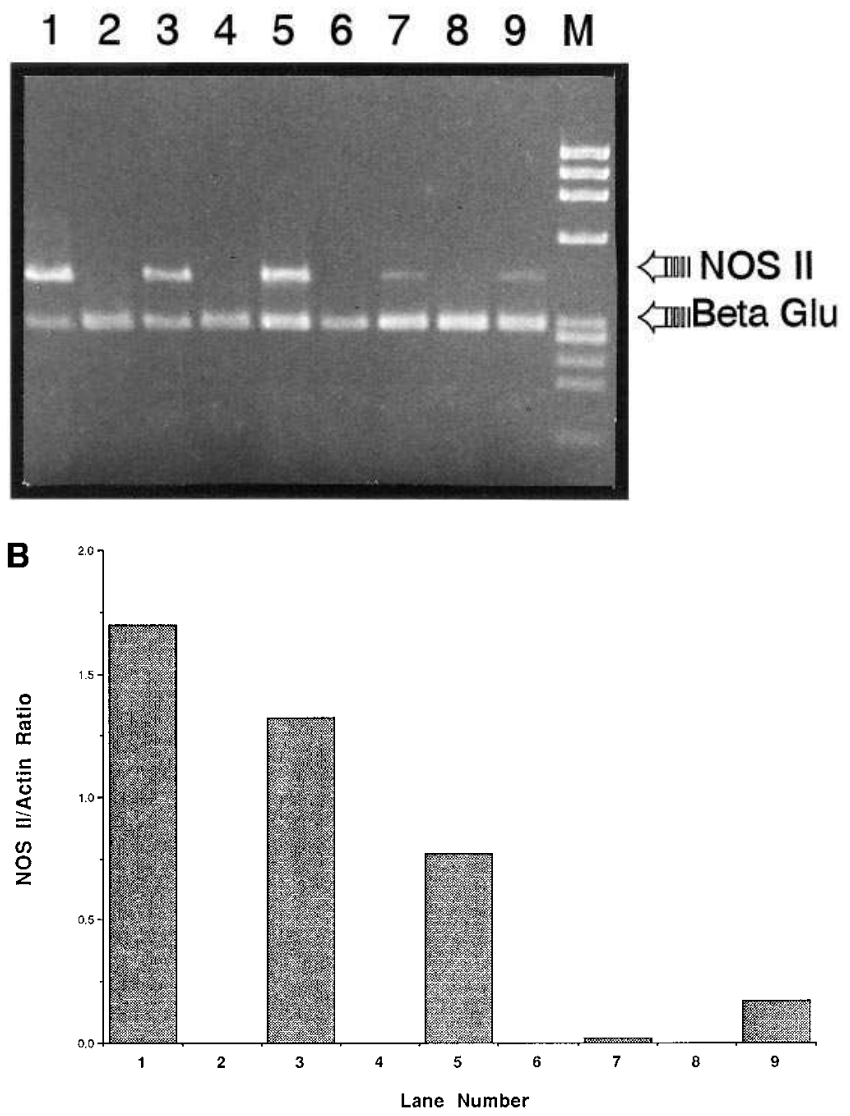

Figure 7. Ethidium bromide-stained agarose gel demonstrating NOS II and $\beta$-glucuronidase gene expression in full thickness colon samples removed from control and TNB-treated rats on day 6 of the study $(A)$. NOS II: $\beta$-glucuronidase ratio results were determined by band densitometry, and these results and a detailed legend of each lane are shown in $B$. See Methods for a detailed description of mRNA isolation and reverse transcriptase PCR parameters. (Lane 1, colitic rat: no virus; Lane 2, control rat: 2 injections of Ad5LacZ; Lane 3, colitic rat: 2 injections of Ad5LacZ; Lane 4, control rat: 1 injection of Ad5IL-4; Lane 5, colitic rat: 1 injection of Ad5IL-4; Lane 6, control rat: 2 injections of Ad5IL-4; Lane 7, colitic rat: 2 injections of Ad5IL-4; Lane 8, control rat: 2 injections of Ad5IL-4; Lane 9, colitic rat: 2 injections of Ad5IL-4.)

TNF $\alpha$, and IFN- $\gamma$ in mesenteric lymph node and liver. However, not all attempts to attenuate experimental IBD with exogenous cytokine administration have shown similar therapeutic effects. The twice daily injection of rhIL-10 into colitic rats failed to attenuate the mucosal injury and nitric oxide synthesis observed on day 5 after TNB (50). This study, unlike the others mentioned above, addressed the effects of exogenous rhIL-10 delivery on nitric oxide synthesis in the gut because it is established that nitric oxide exerts an important pathologic effect in TNB $(32,35)$ and experimental granulomatous colitis (51). IL-10 treatment has also proved to be ineffective in attenuating the onset of colitis in HLA-B27 transgenic rats (52), another model where increased nitric oxide synthesis contributes to colonic and joint injury (53). Whether the failure of IL-10 to attenuate the injury in these models of IBD is directly related to the lack of attenuation of increased nitric oxide synthesis is currently unknown. Thus, regulation of cytokine function during experimental and clinical IBD through the administration of monoclonal antibodies or exogenous cytokine appears to be a very promising therapeutic approach that deserves further study.

Considering the importance of nitric oxide in the development of injury in the TNB-colitis model, we examined the effects of Ad5LacZ and Ad5IL-4 treatment on NOS II gene expression and nitric oxide synthesis. Nitric oxide is now recognized to play a dual role in the gastrointestinal tract (54). Constitutive synthesis of nitric oxide is critical for the maintenance of normal vascular perfusion and epithelial barrier function, and removal of nitric oxide under these conditions has a deleterious consequence for the intestinal tract (for review see reference 54). However, under inflammatory conditions where NOS II gene expression and function are up regulated by bacterial products or de novo synthesize of proinflammatory cytokines, nitric oxide synthesis by this calcium-independent enzyme exerts a deleterious effect on many tissues, including the gastrointestinal tract (55). The appropriate pharmacologic studies have not been performed clinically, but the current data suggest that increased nitric oxide synthesis by NOS II is involved in the tissue injury and dysfunction in IBD, particularly ulcerative colitis $(31,56)$. Experimentally, we have previously shown that the oral administration of L-NAME attenuated most of the mucosal injury observed on day 6 after TNB (32). A major caveat of this and other studies $(33,35,36,51)$ that have used this therapeutic strategy is that L-NAME and other nitric oxide synthase inhibitors such as L-NMMA and aminoguanadine do not selectively inhibit NOS II activity. A selective approach to regulating NOS II activity is found in the ability of IL-4, IL-10, and TGF- $\beta$ to transcriptionally regulate NOS II expression in many cells $(57,58)$. In the intestinal tract, Kolios et al. (59) demonstrated that IL-4, but not IL-10, concentration dependently inhibited the cytokine-induced expression of NOS II and nitric oxide synthesis by human colonic epithelial cells. In the present study, although we cannot comment specifically on the NOS II-expressing cells that were directly affected by the upregulation of IL-4, two injections of

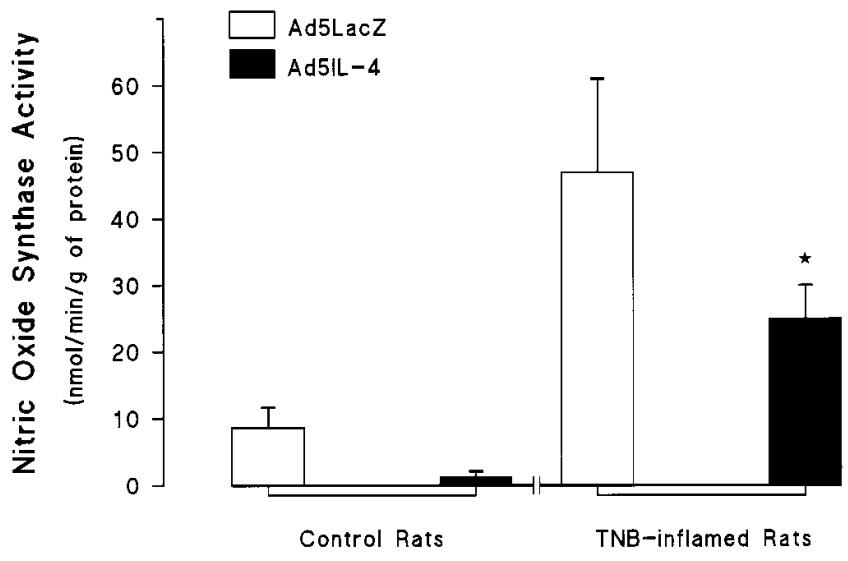

Figure 8. Calcium-independent NOS II nitric oxide synthesis in colons taken from control and colitic rats injected on day 1 and day 3 of the study with Ad5LacZ (open bar) or Ad5IL-4 (solid bar). Data bars represent mean \pm SEM of three rats per dosing group. * $P \leq 0.05$ compared with double-injected Ad5LacZ rats with TNB colitis. 
Ad5IL-4 markedly reduced NOS II gene expression and NOS II synthetic capacity. Thus, direct inhibitory effects of IL-4 on the expression of NOS II in the inflamed intestine may provide additional beneficial effects.

In conclusion, these findings represent the first demonstration of therapeutic Ad5 gene transfer in experimental IBD, and emphasize the need for further studies on the therapeutic potential of cytokine gene transfer in clinical IBD. The transfer of IL-4 to IBD patients using gene therapy may compensate for the recently described mucosal deficit in IL-4 synthesis in these patients (27). However, the effectiveness of human Ad5 expressing human IL-4 in IBD may be hampered by recent observations that certain elements of the immune system in IBD patients have diminished responsiveness to the contrainflammatory actions of IL-4 $(20,60)$. Because IL-13 has many similar immunoregulatory characteristics of IL-4 but recognizes a separate receptor $(59,60)$, it is conceivable that the use of human Ad5 expressing human IL-13 may circumvent this problem. Considering that rhIL-10 has been used successfully to treat clinical IBD (21), delivery of hIL-10 using Ad5based gene therapy certainly warrants further consideration. In addition, other Ad5-delivered therapies that may be beneficial in the treatment of IBD include human versions of antiTNF $\alpha$ (22-24) and possibly anti-IL-12 (37) monoclonal antibodies.

\section{Acknowledgments}

This work was supported by grants from the Medical Research Council of Canada (MRC) to S.M. Collins and J. Gauldie. C.M. Hogaboam is a recipient of an MRC Research fellowship.

\section{References}

1. Ulmer, J.B., J.J. Donnelly, S.E. Parker, G.H. Rhodes, P.F. Felgner, V.J. Dwarki, S.H. Gromkowski, R.R. Deck, C.M. DeWitt, A. Friedman, et al. 1993. Heterologous protection against influenza by injection of DNA encoding a viral protein. Science. 259:1745-1749.

2. Missol, E., A. Sochanik, and S. Szala. 1995. Introduction of murine Il-4 gene into B16(F10) melanoma tumors by direct gene transfer with DNA-liposome complexes. Cancer Lett. 97:189-193.

3. Aramaki, Y., F. Nitta, R. Matsuno, Y. Morimura, and S. Tsuchiya. 1996. Inhibitory effects of negatively charged liposomes on nitric oxide production from macrophages stimulated by LPS. Biochem. Biophys. Res. Commun. 220:1-6.

4. Kass-Eisler, A., K. Li, and L.A. Leinwald. 1996. Prospects for gene therapy with direct injection of polynucleotides. Ann. NY Acad. Sci. 232-240.

5. Graham, F.L., and L. Prevec. 1991. Manipulation of adenovirus vectors. In Methods in Molecular Biology. Gene Transfer and Expression Protocols. E.J. Murray and J.M. Walker, editors. Humana Press Inc., Clifton, NJ. 109-127.

6. Braciak, T.A., S.K. Mittal, F.L. Graham, C.D. Richards, and J. Gauldie. 1993. Construction of recombinant human type 5 adenoviruses expressing rodent IL-6 genes. An approach to investigate in vivo cytokine function. J. Immunol. 151:5145-5153.

7. Vallance, B.A., C.M. Hogaboam, C.L. Addison, J. Gauldie, and S.M. Collins. 1996. Interleukin-4 gene transfer to the intestine causes inflammation and muscle dysfunction in the mouse. Gastroenterology. 110:1034a. (Abstr.)

8. Xing, Z., T. Braciak, M. Jordana, K. Croitoru, F.L. Graham, and J. Gauldie. 1994. Adenovirus-mediated cytokine gene transfer at tissue sites. Overexpression of IL-6 induces lymphocytic hyperplasia in the lung. J. Immunol. 153: 4059-4069.

9. Addison, C.L., T. Braciak, R. Ralston, W.J. Muller, J. Gauldie, and F.L. Graham. 1995. Intratumoral injection of an adenovirus expressing interleukin-2 induces regression and immunity in a murine breast cancer model. Proc. Natl. Acad. Sci. USA. 92:8522-8526.

10. Cayeux, S., C. Beck, B. Dorken, and T. Blankenstein. 1996. Coexpression of interleukin-4 and B7.1 in murine tumour cells leads to improved tumour rejection and vaccine effect compared to single gene transfectants and a classical adjuvant. Hum. Gene Ther. 7:525-529.

11. Schneider, M.D., and B.A. French. 1993. The advent of adenovirus gene therapy for cardiovascular disease. Circulation. 88:1937-1942.

12. Kusugami, K., T. Matsuura, G.A. West, K.R. Youngman, D. Rachmile- witz, and C. Fiocchi. 1991. Loss of interleukin-2-producing intestinal CD4+ T cells in inflammatory bowel disease. Gastroenterology. 101:1594-1605.

13. Sadlack, B., H. Merz, H. Schorle, A. Schimpi, A.C. Feller, and I. Horak. 1993. Ulcerative colitis-like disease in mice with a disrupted interleukin-2 gene. Cell. 75:253-261.

14. Kuhn, R., J. Lohler, D. Rennick, K. Rajewsky, and W. Muller. 1993. Interleukin-10-deficient mice develop chronic enterocolitis. Cell. 75:263-274.

15. Mombaerts, P., E. Mizoguchi, M.J. Grusby, L.H. Glimcher, A.K. Bhan, and S. Tonegawa. 1993. Spontaneous development of inflammatory bowel disease in T cell receptor mutant mice. Cell. 75:275-282.

16. Mizoguchi, A., E. Mizoguchi, C. Chiba, G.M. Spiekermann, S. Tonegawa, C. Nagler-Anderson, and A.K. Bhan. 1996. Cytokine imbalance and autoantibody production in $\mathrm{T}$ cell receptor- $\alpha$ mutant mice with inflammatory bowel disease. J. Exp. Med. 183:847-856.

17. Powrie, F., R. Correa-Oliveira, S. Mauze, and R.L. Coffman. 1994. Regulatory interactions between CD45RBhigh and CD45RBlow CD4 T cells are important for the balance between protective and pathogenic cell-mediated immunity. J. Exp. Med. 179:589-600.

18. Leach, M.W., A.G.D. Bean, S. Mauze, R.L. Coffman, and F. Powrie. 1996. Inflammatory bowel disease in C.B-17 scid mice reconstituted with the CD45RB ${ }^{\text {high }}$ subset of CD4 ${ }^{+}$T cells. Am. J. Pathol. 148:1503-1515.

19. Choi, P.M., and S.R. Targan. 1994. Immunomodulator therapy in inflammatory bowel disease. Dig. Dis. Sci. 39:1885-1892.

20. Schreiber, S., T. Heinig, U. Panzer, R. Reinking, A. Bouchard, P.D. Stahl, and A. Raedler. 1995. Impaired response of activated mononuclear phagocytes to interleukin 4 in inflammatory bowel disease. Gastroenterology. 108:21-33.

21. Schreiber, S., T. Heinig, H.-G. Thiele, and A. Raedler. 1995. Immunoregulatory role of interleukin-10 in patients with inflammatory bowel disease. Gastroenterology. 108:1434-1444.

22. Van Dulleman, H.M., S.J.H. Van Deventer, D.W. Hommes, H.S. Bijl, G.N.J. Jansen, G.N. Tytgat, and J. Woody. 1995. Treatment of Crohn's disease with anti-tumor necrosis factor chimeric monoclonal antibody (cA2). Gastroenterology. 109:129-135.

23. Bauditz, J., Y. Ruckert, A. Raedler, S. Nikolaus, H. Lochs, and S. Schrieber. 1995. Tumor necrosis factor inhibition by oxpentifylline and intestinal inflammation in Crohn's disease. Lancet. 345:1445.

24. Derkx, B., J. Taminiau, S. Radema, A. Stronkhorst, C. Wortel, G. Tytgat, and S. Van Deventer. 1993. Tumor necrosis factor antibody in Crohn's disease. Lancet. 342:173-174

25. Morris, G.P., P.L. Beck, M.S. Herridge, W.T. Depew, M.R. Szewczuk, and J.L. Wallace. 1989. Hapten-induced model of chronic inflammation and ulceration in the rat colon. Gastroenterology. 96:795-803.

26. Wallace, J.L. 1994. Novel targets for anti-inflammatory therapy in IBD. In Inflammatory Bowel Disease. Basic Research, Clinical Implications and Trends in Therapy. L.R. Sutherland, S.M. Collins, F. Martin, R.S. McLeod, S.R. Targan, J.L. Wallace, and C.N. Williams, editors. Kluwer Academic Publishers, London. 374-382.

27. West, G.A., T. Matsuura, A.D. Levine, J.S. Klein, and C. Fiocchi. 1996. Interleukin-4 in inflammatory bowel disease and mucosal immune reactivity. Gastroenterology. 110:1683-1695.

28. Cohen, M.C., and S. Cohen. 1996. Cytokine function: a study in biologic diversity. Am. J. Clin. Pathol. 105:589-598.

29. Gautam, S.C., N.F. Chikkala, and T.A. Hamilton. 1992. Anti-inflammatory action of IL-4. Negative regulation of contact sensitivity to trinitrochlorobenzene. J. Immunol. 148:1411-1415.

30. Snyder, S.H. 1993. Pharmacology: janus faces of nitric oxide. Nature. 364:577-587.

31. Boughton-Smith, N.K. 1994. Pathological and therapeutic implications for nitric oxide in inflammatory bowel disease. J. R. Soc. Med. 87:312-314.

32. Hogaboam, C.M., K. Jacobson, S.M. Collins, and M.G. Blennerhassett. 1995. The selective beneficial effects of nitric oxide inhibition in experimental colitis. Am. J. Physiol. Gastrointest. Liver Physiol. 268:G673-G684.

33. Miller, M.J.S., H. Sadowska-Krowicka, S. Chotinaruemol, J.L. Kakkis, and D.A. Clark. 1993. Amelioration of chronic ileitis by nitric oxide synthase inhibition. J. Pharmacol. Exp. Ther. 264:11-16.

34. Miller, M.J.S., and D.A. Clark. 1994. Nitric oxide synthase inhibition can initiate or prevent gut inflammation: role of enzyme source. Agents Actions. 41(Suppl. C PT 2):C231-C232.

35. Rachmilewitz, D., F. Karmeli, E. Okon, and M. Bursztyn. 1995. Experimental colitis is ameliorated by inhibition of nitric oxide synthase activity. Gut. 37:247-255.

36. Miller, M.J.S., J.H. Thompson, X.-J. Zhang, H. Sadowska-Krowicka, J.L. Kakkis, U.K. Munshi, M. Sandoval, J.L. Rossi, S. Eloby-Childress, J.S. Beckman, et al. 1995. Role of inducible nitric oxide synthase expression and peroxynitrite formation in guinea pig ileitis. Gastroenterology. 109:1475-1483.

37. Neurath, M.F., I. Fuss, B.L. Kelsall, E. Stuber, and W. Strober. 1995. Antibodies to interleukin-12 abrogate established experimental colitis in mice. J. Exp. Med. 182:1281-1290.

38. Elson, C.O., R.B. Sartor, G.S. Tennyson, and R.H. Riddell. 1995. Experimental models of inflammatory bowel disease. Gastroenterology. 109:13441367. 
39. Huard, J., G. Lochmuller, G. Acsadi, A. Jani, B. Massie, and G. Karpati. 1995. The route of administration is a major determinant of the transduction efficiency of rat tissues by adenoviral recombinants. Gene Ther. 2:107-115.

40. Khan, I., and S.M. Collins. 1994. Expression of cytokines in the longitudinal muscle myenteric plexus of the inflamed intestine of rat. Gastroenterology. 107:691-700.

41. Sands, W.A., V. Bulut, A. Severn, D. Xu, and F.Y. Liew. 1994. Inhibition of nitric oxide synthesis by interleukin-4 may involve inhibiting the activation of protein kinase C epsilon. Eur. J. Immunol. 24:2345-2350.

42. Karges, W.J.P., R. Gaedigk, and H.-M. Dosch. 1994. Quantitative analysis of gene expression in different tissues by template-calibrated RT-PCR and laser-induced fluorescence. PCR Methods and Applications. 4:154-159.

43. Lowry, O.H., N.J. Rosebrough, A.L. Farr, and R.J. Randall. 1951. Protein measurement with the Folin phenol reagent. J. Biol. Chem. 193:265-275.

44. Forough, R., D. Hasenstab, N. Koyama, H. Lea, M. Clowes, and A.W. Clowes. 1996. Generating antibodies against secreted proteins using vascular smooth muscle cells transduced with replication-defective retrovirus. BioTechniques. 20:694-696.

45. Juillard, V., P. Villefroy, D. Godfrin, A. Pavirani, A. Venet, and J.-G. Guillet. 1996. Long-term humoral and cellular immunity induced by a single immunization with replication-defective adenovirus recombinant vector. Eur. J. Pharmacol. 25:3467-3473.

46. Morga, E., and P. Heuschling. 1996. Interleukin-4 down regulates MHC II antigens on cultured rat astrocytes. Glia. 17:175-179.

47. Fiorentino, D.F., M.W. Bond, and T.R. Mosmann. 1989. Two types of mouse T helper cells. IV. Th2 clones secrete a factor that inhibits cytokine production by Th1 clones. J. Exp. Med. 170: 2081-2085.

48. Strober, W., and R.O. Ehrhardt. 1993. Chronic intestinal inflammation: an unexpected outcome in cytokine or $\mathrm{T}$ cell receptor mutant mice. Cell. 75 : 203-205.

49. Herfath, H., R. Janardham, H.C. Rath, and R.B. Sartor. 1996. In vivo IL-10 treatment suppresses experimental chronic granulomatous inflammation and has an additive effect with coritcosteroids. Gastroenterology. 110:855a. (Abstr.)

50. Ribbons, K.A., S. Eloby-Childress, J. Thompson, X.J. Zhang, K. Pennline, and M.J.S. Miller. 1996. Effect of interleukin-10 in TNBS-induced colitis in rats. Gastroenterology. 110:856a. (Abstr.)

51. Grisham, M.B., R.D. Specian, and T.E. Zimmerman. 1994. Effects of nitric oxide synthase inhibition on the pathophysiology observed in a model of chronic granulomatous colitis. J. Pharmacol. Exp. Ther. 271:1114-1121.

52. Quere, S., V. Bertrand, M. Tulliez, L. Chauvelot-Moachon, J. Charreirre, and M. Breban. 1996. The effects of IL-10 treatment on the inflammatory bowel disease in transgenic rats expressing HLA-B27 and human $\beta$ microglobulin. Gastroenterology. 110:763a. (Abstr.)

53. Aiko, S., and M.B. Grisham. 1995. Spontaneous intestinal inflammation and nitric oxide metabolism in HLA-B27 transgenic rats. Gastroenterology. 109:142-150.

54. Alican, I., and P. Kubes. 1996. A critical role for nitric oxide in intestinal barrier function and dysfunction. Am. J. Physiol. Gastrointest. Liver Physiol. 270:G225-G237.

55. Miller, M.J.S., and M.B. Grisham. 1995. Nitric oxide as a mediator of inflammation? You had better believe it. Mediat. of Inflamm. 4:387-396.

56. Mourelle, M., F. Casellas, F. Guarner, A. Salas, V. Riveros-Moreno, S Moncada, and J.-R. Malagelada. 1995. Induction of nitric oxide synthase in colonic smooth muscle from patients with toxic megacolon. Gastroenterology. 109:1497-1502.

57. Moncada, S. 1993. The L-arginine: nitric oxide pathway, cellular transduction and immunological roles. Adv. Second Messenger Phosphoprotein Res. 28:97-99.

58. Kusugami, K., A. Fukatsu, M. Tanimoto, M. Shinoda, J.-I. Haruta, A. Kuroiwa, K. Ina, K. Kanayama, T. Ando, T. Matsuura, T. Yamaguchi, K. Morise, M. Ieda, H. Iokawa, A. Ishihara, and S. Sarai. 1995. Elevation of interleukin-6 in inflammatory bowel disease is macrophage- and epithelial celldependent. Dig. Dis. Sci. 40:949-959.

59. Kolios, G., D.A.F. Robertson, and J. Westwick. 1996. Interleukin-13 regulates the nitric oxide production in human colonic epithelial cells. Comparison with interleukin-4 and interleukin-10. Gastroenterology. 110:822a. (Abstr.)

60. Kucharzik, T., N. Lugering, H. Weigelt, M. Adolf, W. Domschke, and R. Stoll. 1996. Immunoregulatory properties of IL-13 in patients with inflammatory bowel disease; comparison with IL-4 and IL-10. Clin. Exp. Immunol. 104:483-490. 